\title{
Increasing Legal Capacity for Communities in the Context of Realizing a Village of Law Awareness and Child Friendly
}

Study of Kedungkelor Village, Tegal Regency, Indonesia

\author{
Bagus Edi Prayogo ${ }^{*}$, Amanah ${ }^{2}$, Tirta Mulya Wira Pradana ${ }^{3}$, \\ Rodiyah ${ }^{4}$ \\ ${ }^{1,3,4}$ Faculty of Law, Universitas Negeri Semarang, Indonesia \\ ${ }^{2}$ Economic Development Department, Faculty of Economics, \\ Universitas Negeri Semarang, Indonesia \\ *Corresponding Author: B.E. Prayogo, bagus21edi@gmail.com
}

\begin{abstract}
The purposes of community services program and research are to support, analyze, and create an accountable, transparent, independent, legally-aware and child-friendly village in Kedungkelor village, Warureja sub-district, Tegal regency. The paper analyzed two major parts are taken in the title of the service as well as aware of the law and child worth. Legal awareness and worthy of children are considered important because the child's world is very determining how the child will grow up later so that the village apparatus and the community need to increase of awareness related to the law and in the policies formulated by the village government or the community itself must be child-oriented. The program implemented a to realize a village that is aware of the law and suitable for children in our service is providing free legal assistance, door-to-door programs for families aware of the law and the environment, leadership training, healthy snacks and hand hygiene programs, and anti-bullying programs. The paper concluded that there are some forms of activity that will initiate the formation of a village that is aware of the law and is suitable for children.

Keywords: child friendly; law awareness; legal capacity; legal services; village community
\end{abstract}

How to cite:

Prayogo, B.E., Amanah, A., Pradana, T.M.W., \& Rodiyah, R. 'Increasing Legal Capacity for Communities in the Context of Realizing a Village of Law Awareness and Child Friendly.' Indonesian Journal of Advocacy and Legal Services, 1(1), 65-78. DOI: 10.15294/ijals.v1i1.33776 


\section{A. Introduction}

Indonesia is a country rich in good diversity ethnicity, religion, and culture, therefore every person held in high esteem on the same rights and duties before the law. or we are familiar with the principle of equality before the law, recognition of Human Rights (HAM) is a matter that must be done by the State of Law, Indonesia as one of the country's law has been expressed both in the preamble and 1945.

Bagir Manan ${ }^{1}$ stated that prior to the 1945 changes, quite evenly opinions of jurists and political experts and observers who said that one of the fundamental flaws of the 1945 Constitution which is set on August 18, $1945^{2}$, Because it does not load or full load of human rights. Indonesian human rights as a paradigm of thought and was not born along with the United Nations Declaration of Human Rights $1948^{3}$,

Human Rights in the 1945 Constitution before the amendment is not listed in a separate Charter but scattered in several articles. Limited and defined briefly. The position of explicitly recognized in constitutional contained in the 1945 Constitution, which is the application as a legal state ideology. As an important element of human rights for the fulfillment of guarantee equality in the welfare and justice, then the most important is the equity of the law without any discrimination in the implementation, the principle of equality before the law emphasizes that each person actually seen not on the basis of the object alone, but as legal subjects.

Synergy between the authorities and the public would have improved its capacity to support the implementation. In fact we often encounter the opposite field where there is friction or turbulence in fulfilling justice in society and citizenship, as if the law becomes sharply downward and upward blunt. So often is known in the community that the law only synonymous with money, prison, and the means to intervene datu each other, but actually the law is there to protect and respect each other.

With the imbalance in this law leads to ignorance anymore or we used to know as apathetic, and if left unchecked will lead to legal uncertainty. if we still can not admit that the legal issues is a disease that we should not be underestimated and leave. As developing countries are heterogeneous certainly often encountered various educational backgrounds and economic

Astim Riyanto,, Pengetahuan Hukum Konstitusi Menjadi Ilmu Hukum Kosntitusi, Jurnal Hukum dan Pembangunan, Vol. 44 No.2 April-June, 2015, pp. 185-208

2 Bagir Manan \& Susi Dwi Harijanti, Konstitusi dan Hak Asasi Manusia. Padjajaran Jurnal Ilmu Hukum, Vol. 3 No. 3 , 2016, pp. 448-467

3 Marilang, Menimbang Paradigma Keadilan Hukum Progresif. Jurnal Konstitusi Vol. 14. No 2, 2017, pp. 315-331 
inequality, and coupled with the industrial revolution 4.0 causing challenges and problems of life which require them to cope and survive even need to be able to innovate. But the dynamics of this kind do not always run smoothly, it gives birth to problems that arise in society of course also related to legal matters therein. One of them in the village Kedungkelor.

Kedungkelor village is a village located in District Warureja Tegal, Central Java. The village is currently Kedungkelor included in the category of developing village. Kedungkelor village has 5 hamlet, 5 neighbourhood dispersed in 3 hamlets namely: Bojongkelor Hamlet, Hamlet Kedungkesambi and geographical panjatan. Condition village hamlet Kedungkelor a low-lying coastal areas or ground height 0:00 $\mathrm{m}$ above sea level. By typological like it then generally Village Kedungkelor has a hot climate. Kedungkelor village is one of the villages that are in the districts of Warureja, Tegal, Central Java province which has an area of $795.00 \mathrm{~m} 2$ with -6.890391,109.307820 coordinates. Kedungkelor north lies the village immediately adjacent to the Java Sea, south by the village Banjarturi, Banjaragung village, District Warureja. East by District pemalang. And west by the village Demangharjo. The Distance Village Kedungkelor the administration center (orbitasi) is as following: Distance to the capital district Warureja: $6 \mathrm{Km}$, Distance from Ibokota Tegal: $27.4 \mathrm{Km}$ Distance from the capital of Central Java Province: $134 \mathrm{Km}$.

Kedungkelor Village area most of the tourism potential of the Sea. This is because it is located fairly close to the coast, the island travel, marine parks, historical sites nautical, and others. Many types of jobs occupied Kedungkelor Village community, such as shrimp farmers, fishermen, farmers, civil servants, artisans jasmine and others. Kedungkelor village has a vast territory with a population that is fairly solid. Kedungkelor village has a natural potential is quite good, especially in the field of fisheries and perekebunan. However, there are serious problems in terms of the organization of village government, giving rise to a lack of public awareness Kedungkelor village.

The lack of public awareness Kedungkelor village had an impact on the number of violations of the existing regulations. Violations are almost done by all the people of the lightest example, littering and violation on a deeper level such heavy traffic violation Habits Village community Kedungkelor who has a level of legal awareness lower will certainly affect the growth and development of children who live in the village. Children who still behave according to what is seen and heard of course will follow the customs of the people around him. When children grow up in an environment that has a low level of legal awareness of the children will 
apply it when he grows up later. In fact, as the future generation is expected to bring the Indonesian nation toward a better again. For that we need to do things that can overcome these problems and make the village into the village proper Kedungkelor children. Son was the forerunner of the nation and the state, which will become the main pillars of development as well determinants atautidaknya quality of Indonesian human resources that need to be considered properly so that the quality of Indonesian children may continue to grow and also get optimal protection dariseluruh society.

Based Population Survey between Census 2015 predicted in 2019 the Indonesian population reached 266.92 million, as for the population in the age group 0-14 years (Age of the children) reached 66.17 million, or approximately $24.8 \%$ of the total population, In accordance with Act No. 23 of 2002 on Protection of Children, with their child protection is useful to ensure the fulfillment of the rights of children to live, grow, develop and participate optimally in accordance with human dignity, and protection from violence and discrimination. ${ }^{4}$

However, the facts show that there is a gap between what is aspired to the real conditions of Indonesian children. Lately we often hear and see the social problems that occur to children and that all deserve special attention, as many children yangterpaksa risk as a result of negligence or incompetence of adults dalammelindungi them, there are cases in manaseorang olds schools must be willing putussekolah order to keep younger siblings because her mother left for a living, in case of murder of children aged three years by his own father, and still adanyakebijakan government in planning the development of a less pro-child.

Beautiful child is a gift for parents. Wherein at every birth of a child becoming a highly anticipated event. Even the process of development and growth of a child would be a serious concern for parents. Educating children is like taking care of a tree where with patience, seriousness can produce the next generation who are able to bring major changes to the nation, with a superior generation, then the quality of human resources (HR) Indonesia as a central pillar of national development, so the need to improve the quality and capacity to get serious protection from the elements of society. Qualified human resources can not be born in an instant, when children are allowed to grow and flourish without the protection and education, then they will be a burden in the future because it has a low power struggle and lack of innovation. whereas their number more than a third of the population of Indonesia. Providing food and clothing are not sufficient to

Zuraidah \& Muhamad Sadi Is Perlindungan Hukum Terhadap Hak Asasi Anak Yang Menjadi Korban Kekerasan, Nurani, Vol 18, No. 1, June, 2018, pp. 151-162 
make the child as an agent of change quality, creative, competitive spirit of nationalism which has the breath of Pancasila.

It takes commitment and a strong awareness that the environment presents a caring and responsive to the interests and needs of children. Children's rights is a part that should not be separated by the Human Rights relating to the role of the state, every state is obliged to protect (melindungi), meet (memenuhi), and respect (menghargai) the rights of children, with the obligation of the state to protect and educating children, the required implementation of policies top to the bottom one with the presence of child-friendly village.

Because children as social beings as well as individual beings, which means that every child was a typical personal style of his personality according to the indispensable protection of children done by the parents or the government, because the child's future is the future of the nation. Do not let children become victims of violence either by the family themselves or carried by people around the neighborhood or the community at large which can make children lose their future. Barda Nawawi Arief explained true in Human Rights (Human Rights) does not distinguish rights from a gender (female or male). Both of are human beings who have the same rights.

Indonesian state guarantees women's rights without discrimination. In the explanation of the Constitution of the Republic of Indonesia Year 1945 stated that Indonesia is a state based on law (Rechtsstaat) is not based on power alone (machtsstaat). As a state child protection measures need to be implemented as early as possible, ie, since the fetus in the womb until the child is aged 18 (eighteen) years. Then the state must provide a real child protection, thorough, and comprehensive, because this law laid the obligation to provide protection to children based on the following principles: a). non-discrimination; b) .Interest is best for the child; c). right to life, survival and development; and D). respect for the views of the child.

Judging from the nature protection, child protection can be divided into juridical protection, including protection in the field of criminal law perdatadan law, and protection of non juridical, including protection in the social and educational fields. ${ }^{5}$

Service Program, strives to provide solutions for problems Legal Capacity for People in the village of Tegal Kedungkelor in Order To Achieve Children's Village Laak and Legal Literacy and Eligible Children. The program involves an element of synergy between village officials, parents, students, and teachers.

5 Maulana Hassan Waddong, Pengantar Advokasi dan Hukum Perlindungan Anak, Jakarta, Gramedia Indonesia, 2000, p. 45. 
The first target is the existence of this service is expected to improve the capacity of law for village officials, community Kedungkelor In the village, in the running of public life in the village. The second with the dedication is expected to make the village as the village is worth a child Kedungkelor.

\section{B. Method}

The paper is focused on on analysing of implementation on improvement the legal capacity on the levers students and teachers as well as establish childfriendly village in the village of Tegal Kedungkelor. The program is also dedicated to village officials, the parents, teachers and of course students in understanding the implementation of education and enhancement legal capacity as a shared responsibility. This devotion Kedungkelor located in the village of Tegal. The method used in the implementation of this service is in several ways, namely: (1) model of lecture door to door, (2) simulation model of educational leadership, (3) training model and Assistance Legal Assistance. Model lectures conducted to introduce the parents by visiting the houses door to door to discuss the importance of education in the context of law and human rights. Model simulations more encourage students to simulate a variety of issues in education and how to deal with it. Model training and mentoring models of legal aid made to see the development of legal capacity for village officials, parents and teachers in dealing with cases in the community

\section{Result and Discussion}

Community Service held in the village Kedungkelor, District Warureja lasted for 45 days, from July 15 until August 26, 2019, with a superior program that Law and Eligible Children Village.The result of the program describe and explain as follows.

1. Implementation of Legal Capacity for Establishment of Law Awareness in Legal Services Sector

In the legal services sector, in order to create a society that is aware of the law, has implemented several program, as follows:

a. Establishment of Legal Aid Center

Legal Aid Center or Legal Aid Post (hereinafter called as POSBANKUM) is a legal services specifically given to the people who need a defense free of charge, both outside and inside the court, in criminal, civil 
and administrative, from someone who understands the ins and outs of legal defense, the principles and the rule of law, and human rights. In law it is said, is a legal aid service law given by the legal aid free of charge to the recipient of legal aid. So that legal aid is provided free of charge or not charge. In this legal aid services can include the provision of information, consultation, advice and the making of a claim/appeal in court. ${ }^{6}$

In practice, the Legal Aid Post held on two points, the first is the Kedungkelor village hall, village hall chosen because in addition to its strategic location, Village Hall is also a place that has been known and known by the whole community. The second point is on one of the device houses the village, in the hamlet Bojongkelor, the location was chosen as a strategic place and also a location that is already known by the public, as before, they had become a fixed location RUSELA activity (Rumah Sehat Lansia, Home Healthy Elderly) Melati Putih. POSBANKUM Event held every Monday to Friday, at 09.00-15.00 hrs.

\section{b. Legal Aware Family Socialization (KADARKUM, Keluarga Sadar Hukum)}

Conscious Family Law, here in after abbreviated family aware of the law is one method of legal education as a container that serves to collect citizens on their own accord seeks to raise awareness of the law for themselves. ${ }^{7}$ This is a star family aware of the law up of the establishment of Legal Aware Village.

In practice, socialization Family Literacy Law implemented in two activities: socializing in one place and socialization by visiting houses (door to door), socialization in one place, held on July 21, 2019, which is housed in Smart House Village Kedungkelor, whereas socialization by means of Door to Door held for 3 days, on 6-8 August 2019, which is implemented evenly in

6 Frans Hendra Winarta. 2000. Bantuan Hukum Suatu Hak Asasi Manusia Bukan Belas Kasihan, Jakarta, Elex Media Komputindo, p. 23; Suradji, Etika dan Penegakan Kode Etik Profesi Hukum (Advokat), Badan Pembinaan Hukum Nasional Departemen Hukum dan HAM RI, Jakarta, 2008, p. 77; YLBHI, Panduan Bantuan Hukum di Indonesia, Yayasan Obor Indonesia, Jakarta, 2014, p. 462; Suyogi Imam Fauzi \& Inge Puspita Ningtyas, Optimalisasi Pemberian Bantuan Hukum Demi Terwujudnya Access to Law and Justice Bagi Rakyat Miskin, Jurnal Konstitusi, Vol. 15 No. 1, March, 2018, pp. 58-59; Frans Hendra Winata, Probono Publico, Hak Konstitusional Fakir Miskin Untuk Memeperoleh Bantuan Hukum, PT. Gramedia Pustaka Utama, Jakarta, 2009, p. xii.

7 Batari Laskarwati, Implementasi Nilai Kemanfaatan Hukum dalam Pencegahan Penyalahgunaan Narkoba Melalui Lomba Keluarga Sadar Hukum (KADARKUM), Lex Scientia Law Review. Vol. 2 No. 1, May, 2018, p. 54; Ibrahim Ahmad, Rencana Dan Strategi Peningkatan Kesadaran Hukum Masyarakat, Gorontalo Law Review. Vol. 1 No. 1, April, 2018, p.16. 
three hamlets namely Kedungsambi hamlet, hamlet and hamlet Panjatan Bojongkelor.

c. Aware Village embodiment Law and the Environment

Realizing people who are not blind to the law is a challenge to the rule of law such as Indonesia. Thus the villagers realize the litigious and conscious also of the environment is necessary. The expected target is as follows

i. Educate and enlighten the villagers about the importance of legal literacy

ii. Provide legal assistance to the public so that people feel the presence of law around the community

iii. Provide education and public awareness related to the environment both in environmental management, awareness, education, as well as in law.

\section{Implementation of Legal Capacity on Child Friendly Village Establishment in Kedungkelor Village}

Friendly Children Villages is a condition in an environment where children feel free to play, appreciated its existence and also a lot of activities that are relevant to children. To make it happen, then in this devotion, there are several programs that we do, in order to create child-friendly village, as follows.

\section{a. Anti Bullying Education}

The school is one place that should be a safe, comfortable, and conducive to the people in it, including students. But the phenomenon is happening today is not so, as an example of the bullying activity not only among students and even students to teachers. Some studies suggest that victims of bullying being personally shy, passive, depressed, traumatized and withdraw from social. In addition to the victim, bullying also have an impact on the perpetrators themselves. Perpetrators be individuals with the level of anger and depression, tend to join in criminal activity, and has no empathy.

Most cases of bullying occur due to lack of knowledge and a good understanding of the students themselves as well as school and family members about bullying and what impact resulting from these activities, so that the perpetrators do not feel it is something quite disturbing even lead to danger. Based on these explanations, the students will provide psychoeducation about bullying activity with students better understand the expectations so it does not do so in the future. 
Socialization is done to children is also needed attention and guidance from parents and the surrounding environment. The participation of parents is vital in guiding a child to bersosialsasi and mengebangkan potential of children so that children do not fall into adverse environmental conditions such as harassment. Indicators crucial role of parents can be observed with their child's behavior when socializing, there occurs a change how children face environment. Now therefore, one in the village Kedungkelor service programs also focuses on Anti-Bullying Education, which was held on 25-26 July 2019, which was implemented in two places, namely Kedungkelor 01 Elementary School, and Elementary School Education Kedungkelor 02.

Anti Bullying implemented with the goal of 3rd grade elementary school students, in this case because at the age that students sedangn in a period of growth and development that will be very active, if the age is not introduced to things that are good, the future for tumbub fireworks and the active period is actually may be directed to things that postitif one through bullying.

\section{b. Leadership Training}

Studying in school is important, but besides that students should also be balanced with a good character ownership. This is particularly important given the many examples of cases in Indonesia, which shows the decline in the character and morals of the nation, such as drug abuse, sex, fights, and many more. So far that has happened is designed character education in the form of religious studies, civics, or manners in which it is only a cognitive understanding. The character education program should also be internalized by the participants of affection for and then implemented in day-to-day activities. ${ }^{8}$

Characters are formed inside these students will eventually also affect students in determining their future, as examples of students who do not have a position strong, easily affected by the environment would be perpetrators of conformity, such as attending school activities just because most of her friends to follow, when students were not have an interest in it. Departing from the problem, it needs to be instilled self-leadership or leadership characters themselves who will make the students better understand about themselves, understand the purpose or ideals, and to develop a strategy to achieve it.

\footnotetext{
8 Tirta Mulya Wira Pradana, Model Pengajaran Hak Asasi Manusia (Antara Tekstual Dan Kontekstual), Prosiding Semdikjar ke-II 4 August, 2018,pp. 1161-1168.
} 
Therefore, it needs to be grown character of a leader for the younger generation, which is in the service, has implemented a Training Activity Leadership was held on July 23, 2019, which is housed in Junior High School 1 Warureja, whose target is a member of the student council of Junior High School 1 Warureja, it is because the members of the council who usually become role models for other students, so it is necessary if introduced to educational leadership.

\section{c. Gareng (Gemar Ngaji Bareng)}

Qur'an refers to the activity of reading the Qur'an or discuss books by Muslims. These activities include worship in the Islamic religion and those who do will be rewarded by God. In language Koran has a sense of learning or studying. Qur'an courses together is done in an effort to educate the younger generation especially the field of Islamic knowledge. The benefits of this program of work is as a place for children to learn the Qur'an, so that children are more optimal in reading the Koran. The purpose of the Gareng (Gemar Ngaji Bareng) is to improve religious values and create akhlakul karimah in children early age.

In practice, this activity is carried out in TPQ Kedungkelor, namely the Islamic video playback is also providing motivation of gratitude, sincerity and recognition that a smile is worship.

\section{d. Hands Hygiene and Healthy Food Education}

Childhood identical with their penchant for eating good food diverse sweet or other flavors. Unfortunately craze these children is often underestimated by parents or allow them to eat the food they like regardless of the impact on the health of the body. Parents often less oversee the activities of this child, especially when they are in school, they often buy food less healthy basic ingredients, such as food with excess oil, dip dye, and ice in plastic packaging that are less clean. Coupled with children who do not understand about the germs in their body, especially hands when going to eat they do not wash properly or even not wash.

It is certainly quite disturbing if left unchecked, because it can lead children to various diseases, especially in the digestive tract. Therefore, students took the initiative to teach children about how to wash hands properly, and how to choose healthy snacks to be consumed.

In practice, Gestures Clean and Healthy Snacks socialization and practices implemented in five places, namely in the Primary School Kedungkelor 01, Primary School Kedungkelor 02, Panjatan early childhood education, early childhood and early childhood Anugerah Tunas Bangsa. Its activities include socializing the form of materials, followed by a clean hand washing practices. 


\section{e. Embodiment of Fiendly Children Village}

Same with the concept of decent Children's City, Village Eligible Children also fulfillment of child rights strategy (PUHA) as homage, which means doing the integration of children's rights into:

i. Each formulation process: policy, programs and activities.

ii. Each stage of development: planning and budgeting, implementation, monitoring and evaluation.

iii. Each regional level: national, provincial, district / city, district, to the village / village

In addition, child-friendly village is later to realize the City of eligible children in the county or city and make Indonesia Eligible Children. Eligible Children program will realize several things, including:

1) Mainstreaming fulfillment of child rights (PUHA)

That is an effort to integrate the fulfillment of children's rights in the legislative regulations, policies, programs and activities mulaidari the planning, implementation, evaluation pemantauandan in principle to provide the best interests of the child

2) Institutional strengthening

That is an attempt to strengthen the institutional PP danPA, Non Governmental Organizations (NGO) and DuniaUsaha in all areas of government administration to be proactive in trying to address child rights yangdilakukan through advocacy, outreach and fasilitasidi the field of energy, budget, infrastructure, methods and technologies.

3) Expansion of the range

Namely to build a pilot area county, district, sub-district and village / sub sertakawasan eligible children at the center of economic growth then replicate into the buffer zone and the border areas and the outer islands.

4) Build a network

Developing cooperation and commitment of policy operationalization Village Eligible Children with institutions working in the field of planning and urban development, spatial planning, the relevant task forces and substantial build Eligible Children Village.

5) Institutionalization and familiarization Eligible Children Village.

Namely institutionalizing and sikapdan cultivate friendly behavior towards the child from the family environment and the core of a large family (nucleous and etenedfamilies) to ensure intergenerational interaction that children, adults, the elderly and the elderly. This meant that the noble values of national culture does not disappear or fade. 
6) Promotion, Communication, Information, and Education (PKIE). That is an attempt to capitalize on dalammembangun media communication and mutual understanding, dissemination of information and memberikanedukasi on society in instituting and cultivate Eligible Children Village. Tersebutdiklasifikasikan media into the media room, outdoor, print, electronic and web-based electronic media or social media networks.

7) Certification and appreciation

That is an effort to provide certificates of attainment and achievement award in developing village Village .Apresiasi Eligible Children Eligible Children categorized into groups: pratama, middle, nindya, main and Eligible Children Village.

\section{Conclusion}

The conclusion of the article submission is that in realizing Aware Village Law and Eligible Children need to be done through several activities, including through socialization conducted in general, and in particular (door to door), with regard to the introduction of the law in the community and in statecraft, so aim to build a strong community of its own accord seeks to raise awareness of the law for themselves, can be realized. Meanwhile, to realize village eligible children, also need to do some activities related to the increase in the potential of the child, such as leadership training, educational wash your hands clean and healthy snacks, the movement of the Koran together and educational anti-bullying, so aim to create an environment that is caring and respect children's rights can be realized.

\section{E. Acknowledgments}

Community Service Program in Rural Kedungkelor a Field Work Experience Program (KKN) Scientific Legal Affairs, Semarang State University. In practice, of course a lot of us would like to thank to multiple parties, as follows: Dr. Rodiyah, S.Pd., SH, M.Sc., as the Dean of the Faculty of Law at the same time Field Supervisor, KKN Scientific Kedungkelor village, which has given a lot of support in the preparation and execution of any work program, Mr Adi Warnoto Kedungkelor along with all the Village, which has earned our arrival and also helped in every implementation of the work program and Kedungkelor entire village community that has received the Scientific KKN Team Unnes University, and full of enthusiasm. 


\section{F. Declaration of Conflicting Interests}

The authors state that there is no potential conflict of interest in the research, authorship, and / or publication / publication of this article.

\section{G. Funding}

Program of the community services and research funded by Authors it self as well as publication. Authors declare that there is no sponsorhip or any other parties funded the program.

\section{H. References}

Fauzi, S.I., \& Ningtyas, I.P. (2018). Optimalisasi Pemberian Bantuan Hukum Demi Terwujudnya Access to Law and Justice Bagi Rakyat Miskin. Jurnal Konstitusi. 15(1), 51-72.

Ibrahim, A. (2018). Rencana Dan Strategi Peningkatan Kesadaran Hukum Masyarakat. Gorontalo Law Review. 1(1), 15-24.

Laskarwati, B. (2018). Implementasi Nilai Kemanfaatan Hukum dalam Pencegahan Penyalahgunaan Narkoba Melalui Lomba Keluarga Sadar Hukum (KADARKUM). Lex Scientia Law Review. 2(1), 47-64.

Manan, B., \& Harijanti, D.S. (2016). Konstitusi dan Hak Asasi Manusia. Padjajaran Jurnal Ilmu Hukum. 3(3), 448-467.

Marilang. (2017), Menimbang Paradigma keadilan Hukum Progresif. Jurnal Konstitusi. 14(2), 315-331.

Pradana, T.M.W. (2018). Model Pengajaran Hak Asasi Manusia (Antara Tekstual dan Kontekstual). Prosiding Semdikjar ke-II, ISSN 25986139, 4 August, 1161-1168. Retrieved from http://conference.unpkediri.ac.id/index.php/semdikjar/semdikjar2/pap er/viewFile/260/219

Riyanto, A. (2015), Pengetahuan Hukum Konstitusi Menjadi Ilmu Hukum Kosntitusi. Jurnal Hukum dan Pembangunan 44(2), 185-208.

Republik Indonesia. (2011). Undang-Undang Nomor 16 Tahun 2011 tentang Bantuan Hukum. Kementrian Hukum dan HAM RI, Lembaran Negara Republik Indonesia Tahun 2011 No. 104, Menteri Sekretaris Negara: Jakarta

Suradji. (2008). Etika dan Penegakan Kode Etik Profesi Hukum (Advokat). Jakarta: Badan Pembinaan Hukum Nasional Departemen Hukum dan HAM RI. 
B.E. Prayogo, et.al.

Waddong, M.H. (2000). Pengantar Advokasi dan Hukum Perlindungan Anak. Jakarta: Gramedia Indonesia.

Winarta, F.H. (2000). Bantuan Hukum Suatu Hak Asasi Manusia Bukan Belas Kasihan. Jakarta: Elex Media Komputindo.

Winata, F.H. (2009). Probono Publico, Hak Konstitusional Fakir Miskin Untuk Memeperoleh Bantuan Hukum. Jakarta: PT. Gramedia Pustaka Utama.

YLBHI. (2014), Panduan Bantuan Hukum di Indonesia. Jakarta: Yayasan Obor Indonesia.

Zuraidah, \& Sadi Is, M. (2018). Perlindungan Hukum Terhadap Hak Asasi Anak Yang Menjadi Korban Kekerasan. Nurani. 18(1), 151-162.

Copyrights (C) 2019 by Auhtor(s). This work is licensed under a Creative Commons Attribution-NonCommercial-ShareAlike 4.0 International License. All writings published in this journal are personal views of the authors and do not represent the views of this journal and the author's affiliated institutions. 